Canadian University Music Review

Revue de musique des universités canadiennes

Helmut Kallman, ed. The Canadian Musical Heritage - Le

Patrimoine musical canadien. Vol. 8. Music for Orchestra I /

Musique pour orchestre I. Ottawa: Canadian Musical Heritage

Society, 1990. xxvi, 272 pp. ISBN 0-919883-09-5

\title{
Jack Behrens
}

Volume 11, numéro 2, 1991

URI : https://id.erudit.org/iderudit/1014203ar

DOI : https://doi.org/10.7202/1014203ar

Aller au sommaire du numéro

\section{Éditeur(s)}

Canadian University Music Society / Société de musique des universités canadiennes

\section{ISSN}

0710-0353 (imprimé)

2291-2436 (numérique)

Découvrir la revue

\section{Citer ce compte rendu}

Behrens, J. (1991). Compte rendu de [Helmut Kallman, ed. The Canadian Musical Heritage - Le Patrimoine musical canadien. Vol. 8. Music for Orchestra I / Musique pour orchestre I. Ottawa: Canadian Musical Heritage Society, 1990. xxvi, 272 pp. ISBN 0-919883-09-5]. Canadian University Music Review / Revue de musique des universités canadiennes, 11(2), 146-148. https://doi.org/10.7202/1014203ar

(c) Canadian University Music Society / Société de musique des universités canadiennes, 1991
Ce document est protégé par la loi sur le droit d'auteur. L'utilisation des services d'Érudit (y compris la reproduction) est assujettie à sa politique d'utilisation que vous pouvez consulter en ligne.

https://apropos.erudit.org/fr/usagers/politique-dutilisation/ 
HELMUT KALLMANN, ed. The Canadian Musical Heritage - Le Patrimoine musical canadien Vol. 8. Music for Orchestra I/Mususique pour orchestre I. Ottawa: Canadian Musical Heritage Society, 1990. xxvi, 272 pp. ISBN 0919883-09-5

A welcome addition to the anthology of early Canadian music published by the Canadian Musical Heritage Society is Music for Orchestra I/Musique pour orchestre I edited by Helmut Kallman.

Preceding the scores themselves is a brief account of orchestral composition in Canada from ca. 1790 to ca. 1925 as well as introductory commentary, critical notes, and the "reception history" of the seven works included in the present volume.

In response to this reviewer's inquiry Dr. Kallman advised that parts for Rodolphe Mathieu's Trois Préludes (1912-15) and Ernest MacMillan's Overture (1924) are available for rental from the Canadian Music Centre (although copyright restrictions may apply to the former); a set of parts for Guillaume Couture's Rêverie (ca. 1873-75) belongs to the CBC Toronto Music Library; parts for Antoine Dessane's Overture en fa (1863), Joseph Vézina's "Ton sourire" (1882), W.O. Forsyth's Romanza (ca. 1886-88) and Clarence Lucas's Overture - "Macbeth" (ca. 1900) are available from CMHS on rental.

To present-day ears the most intriguing of these compositions may be Mathieu's Trois Préludes - the contemporaneous and almost identical piano version appears in CMH 6. Composed in his early twenties, the opening movement Sur un nom (1912) is reminiscent of Tristan. The second movement Vague... (1914) is less obviously indebted to the past; the third, Une Muse (1915), however, is unmistakably of the twentieth century. (Perhaps an enterprising conductor might program or record the piano and orchestral versions side by side).

As Helmut Kallmann observes in his introduction, rather than a "history of orchestral composition" in 19th- and early 20th-century Canada there is instead a "common bond" of "admiration of certain European master composers" (Beethoven, Berlioz, Tchaikovsky, Wagner) - to this, most who peruse this volume would, I surmise, agree although to point out specific instances of motivic resemblance may be little more than the equivalent of name dropping. Kallmann observes for example that a motive in Dessane's Overture (measures 10-13) is "best known from the finale of Mozart's "Jupiter" Symphony. More interesting however is a comparison with a passage from the first movement of that composer's Symphony in $B^{b}$, K. 319 (No. 33)." What this reviewer (not being in a position to judge the extent of Dessane's acquaintance with Mozart's symphonic output, finds most interesting is the fact that Dessane derives the 
motive in question from the eighth through eleventh counts of the four-measure three quarter time theme which opens his overture. This could lead to interesting speculation!

Be that as it may, each listener will likely discover echoes of earlier European music throughout this volume, although when one encounters a certain passage in Couture's Rêverie that bears a striking resemblance to Wagner's Tannhäuser as well as to Schubert's Auf dem Wasser zu singen, one recalls R. Murray Schafer's speculation in the programme note to his Son of Heldenleben (1968) that if one could accept "a circular time as conceived by the Greeks..." the "prior discovery of ideas...has no meaning."

Common to all seven works is the expertness of orchestration which not surprisingly often leans toward the heavy rather than the transparent, with sonority triumphing over content. As Kallmann observes, the instrumentation of Vézina's "Ton sourire" (Grande Valse de concert) could easily be reduced; at a time when even the Ravel Trio is re-scored for harp and winds surely a Palm Court Orchestra will soon discover the infectiousness of Vézina's waltzes.

In Lucas's Macbeth, both the scoring "for Grand Orchestra" and the sense of drama are striking. Unstinting in the employment of percussion (timpani, side drum, cymbals, triangle) and bolstered with piccolo, double bassoon ad lib., and wind writing in the higher registers, this work - the material of which is no more vacuous than that of Shostakovich's Festive Overture - likely comes close to equalling the latter's bombast.

Forsyth in his Romanza (dedicated to an "esteemed friend and teacher...") with its copious indications (espress., tranquillo, con passione, con tenerezza), a harp flourish, a solo violin "cadenza ad lib." and an ornate orchestration with simultaneous quarter, eighth, sixteenth notes, and triplets was seemingly attempting to demonstrate his grasp of learning and detail. MacMillan's Overture is admirably crafted and by contrast somewhat more restrained and controlled although verging at times on the predictable.

Reproductions of the first manuscript page of the Dessane, Vézina, and Forsyth works are provided; readers of the Review - composers and copyists especially - will probably view charitably the minor discrepancies between these facsimiles and the new computer engravings, for it is likely that the editorial board compensated many times over for oversights by the seven composers (and their editors) represented in this volume. Such discrepancies or omissions that remain will doubtless be filled in or compensated for instinctively by experienced musicians. Bibliophiles might wish to note that for the Mathieu composition Source B is ms. CMC copy: (CanTcm), 29 pp. 
Now that this laudable tenth volume of early Canadian music published by the Canadian Musical Heritage Society is at hand, one can hope that the special gala concert (11 July 1990) by the National Arts Centre Orchestra, Victor Feldbrill, conductor, which launched this publication and included all but the MacMillan work will be rebroadcast by the $\mathrm{CBC}$ or otherwise be made available as an audible realization of this intriguing music.

Jack Behrens

CanMus Documents 1 - Hymn Tunes in Canada, John Beckwith, ed. Toronto: Institute for Canadian Music, 1987. 165 pp. 0-7727-8550-3

CanMus Documents 2 - Hello out There!, John Beckwith and Dorith Cooper, eds. Toronto: Institute for Canadian Music, 1988. 197 pp. 0-7727-8551-1

CanMus Documents 4 - Three Studies. Toronto: Institute for Canadian Music, 1989. 194 pp. 0-7727-8554-6

The three volumes discussed in this review were published under the auspices of the Institute for Canadian Music which, together with the Jean A. Chalmers Chair of Canadian Music, was established in 1984 at the University of Toronto through the generosity of the Floyd S. Chalmers family. Since its inception, the Institute has initiated and sponsored extensive work in such areas of Canadian music as musicology, ethnomusicology, composition, music education, and performance. The first occupant of the Chalmers Chair was John Beckwith, who retired from the position in 1989. Beckwith was a perfect choice to run the Institute and hold Canada's first chair in Canadian music. He was (and is) well known as a composer, educator, administrator, pianist, and scholar, and, in 1984, he was recognized for his contribution to Canadian music when he was named "Composer of the Year" by the Canadian Music Council. Although he has retired Beckwith remains an active spokesperson and promoter of Canadian music.

Since it was established in 1984, the Institute has organized several conferences on topics pertaining to Canadian music. Two of these conferences took place in 1986, the International Year of Canadian Music: "Sing Out the Glad News: Hymn Tunes in Canada" was held in February, and "Hello Out There! Canada's new music in the world, 1950-85" was held in November. The Proceedings of both conferences are published respectively in CanMus Documents 1 and CanMus Documents 2.

The first conference took the form of seven paper presentations, a concert, and displays. That conference was a continuation of Beckwith's work on hymnody 